\title{
Effects of the dose and viability of Saccharomyces cerevisiae. 2. Ruminal fermentation, performance of lactating dairy cows, and correlations between ruminal bacteria abundance and performance measures
}

\author{
Y. Jiang, ${ }^{*}$ I. M. Ogunade, ${ }^{*}$ † K. G. Arriola, ${ }^{*}$ M. Qi, $\ddagger$ D. Vyas, ${ }^{*}$ C. R. Staples,${ }^{*}$ and A. T. Adesogan ${ }^{* 1}$ \\ *Department of Animal Sciences, University of Florida, Gainesville 32611 \\ †Division of Food and Animal Science, Kentucky State University, Frankfort 40601 \\ ‡DuPont Pioneer, Johnston, IA 50131
}

\begin{abstract}
This study examined effects of the dose and viability of supplemented Saccharomyces cerevisiae yeast strain YE1496 on ruminal fermentation and performance of lactating dairy cows. A second objective was to examine correlations between ruminal bacteria abundance and performance measures. Four ruminally cannulated lactating cows (284 \pm 18 days in milk) were assigned randomly to 1 of 4 treatment sequences in a $4 \times 4$ Latin square experimental design using four 21-d experimental periods. Cows were fed a nonacidotic total mixed ration comprising $22.5 \%$ starch (minimum ruminal $\mathrm{pH}$ $>5.8), 41.7 \%$ corn silage, $7.60 \%$ wet brewers grain, and $50.7 \%$ concentrate on a dry matter (DM) basis. The diet was supplemented with no yeast (control), a low $\left(5.7 \times 10^{7} \mathrm{cfu} / \mathrm{d} ; \mathrm{LLY}\right)$ or high $\left(6.0 \times 10^{8} \mathrm{cfu} / \mathrm{d} ; \mathrm{HLY}\right)$ dose of live yeast, or a high dose of killed yeast $(6.0 \times$ $10^{8} \mathrm{cfu} / \mathrm{d}$; killed by heating at $80^{\circ} \mathrm{C}$ for $1.5 \mathrm{~h}$; HDY). Milk production and composition were measured twice daily from d 11 to 21 of each period, and rumen fluid samples were collected on d 21. In vivo digestibility was measured using chromic oxide as a marker. Pearson correlation analysis was used to assess whether animal performance parameters were correlated with relative abundance (RA) of ruminal bacteria. Supplemental LLY increased yields (kg/d) of milk (29.6 vs. 31.7) and milk protein (0.95 vs. 1.03), tended to increase milk fat yield (1.10 vs. 1.17) and ruminal acetate:propionate ratio (1.92 vs. 2.21), and increased in vivo apparent digestibility (\%) of DM (64.5 vs. 69.1), neutral detergent fiber (NDF; 45.0 vs. 54.5), and $\mathrm{ADF}$ (53.1 vs. 60.9) compared with the control. Feeding HLY had no effects on milk yield compared with the control (30.0 vs. 29.6 $\mathrm{kg} / \mathrm{d}$ ). Feeding HDY tended to increase in vivo digestibility (\%) of NDF (45.0 vs. 50.7), ADF (53.1 vs. 57.7),
\end{abstract}

Received November 29, 2016.

Accepted June 7, 2017.

${ }^{1}$ Corresponding author: adesogan@ufl.edu and the ruminal concentration of lactate (0.78 vs. 2.82 $\mathrm{m} M$ ) but did not affect milk yield compared with the control. Dry matter and NDF digestibility correlated negatively with RA of unclassified Lachnospiraceae in both solid ( $\mathrm{r}=-0.50$ and -0.52 , respectively) and liquid ( $\mathrm{r}=-0.56$ and -0.57 , respectively) fractions, whereas milk yield correlated positively with RA of Lachnospiraceae [Ruminococcus] (an incompletely classified genus; $r=0.43)$ in the solid ruminal fraction. Supplemental LLY, HLY, or HDY increased or tended to increase DM, NDF, and ADF digestibility, but only LLY increased yields of milk, milk fat, and milk protein. Key words: dairy cow, killed yeast, live yeast, milk yield

\section{INTRODUCTION}

Yeast products based on Saccharomyces cerevisiae have been used as feed additives in the dairy industry for more than $20 \mathrm{yr}$ with variable efficacy. Although several studies have observed increased milk production with live yeast supplementation in lactating dairy cows (Desnoyers et al., 2009; Moallem et al., 2009; de Ondarza et al., 2010), no effects were observed in others (Hasunuma et al., 2016; Ouellet and Chiquette, 2016). In meta-analytical or systematic literature summaries of effects of supplementation with live yeast (Desnoyers et al., 2009; de Ondarza et al., 2010), milk production was increased but effects on DMI were inconsistent. Yeast additives presumably exert beneficial effects via stabilizing ruminal $\mathrm{pH}$ by inhibiting lactate production (Chaucheyras-Durand et al., 2005) or increasing lactate utilization (Lynch and Martin, 2002; Fonty and Chaucheyras-Durand, 2006) along with increasing total-tract OM (Desnoyers et al., 2009; Ferraretto et al., 2012) and NDF digestibility (Ferraretto et al., 2012), partly via increasing the number of ruminal cellulolytic bacteria (Newbold et al., 1996; Mosoni et al., 2007). Live yeast may scavenge trace amounts of ruminal oxygen and, by increasing the redox potential 
of ruminal contents, increase the population of anaerobic bacteria and VFA production in the rumen (Fonty and Chaucheyras-Durand, 2006; Jouany, 2006; Marden et al., 2008). Beneficial effects of yeast cultures that contain no live yeast have been attributed to functional metabolites that include uncharacterized yeast growth factors, B vitamins, AA, organic acids, and other fermentation products that stimulate bacterial growth and lead to increased microbial protein production, fiber digestion, or increased utilization of fermentation end products (Miller-Webster et al., 2002; Moallem et al., 2009; Robinson and Erasmus, 2009). Like yeast cultures, inactivated or killed yeast may influence ruminal fermentation by supplying nutrients to autochthonous microorganisms (Oeztuerk, 2009; Opsi et al., 2012). Vyas et al. (2014) reported increased ruminal $\mathrm{pH}$ and greater relative abundance (RA) of Ruminococcus flavefaciens in the solid ruminal fraction of beef heifers in response to killed yeast supplementation. Yet very few studies on killed yeasts exist and, to our knowledge, no previous study has simultaneously compared the effects of the dose and viability of the same yeast strain on ruminal fermentation, microbial diversity, diet digestibility, and animal performance in lactating dairy cows. Such comparisons are needed to better understand the mode of action of yeast and to comprehend the specific roles of the dose and viability of yeast in improving the performance of lactating dairy cows.

Jami et al. (2014) reported that the abundance of various rumen bacterial taxa and milk composition or feed efficiency are highly correlated, suggesting that the bacterial community plays an important role in regulating host physiological parameters. Several studies have reported the effect of yeast supplementation on the abundance of cellulolytic bacteria (Callaway and Martin, 1997) and lactate-utilizing bacteria (Chaucheyras et al., 1996; Rossi et al., 2004), but none have examined associations between abundance of unknown and known bacterial taxa and performance measures in cows supplemented with or without yeast.

The first objective of this study was to examine the effects of the dose and viability of a new $S$. cerevisiae yeast strain YE1496 on ruminal fermentation, digestibility, and performance of lactating dairy cows. The second objective was to explore associations between animal performance measurements and ruminal bacteria abundance. We hypothesized that yeast supplementation would improve rumen fermentation by increasing rumen $\mathrm{pH}$ or total VFA concentration, in vivo apparent digestibility, and milk yield; that the higher dose of live yeast would be the most effective treatment; and that killed yeast would be the least effective dietary treatment. We also hypothesized that animal perfor- mance measurements would positively correlate with abundance of ruminal cellulolytic bacteria. A companion study examined effects of the same treatments on ruminal microbial diversity (Jiang et al., 2017).

\section{MATERIALS AND METHODS}

All experimental cows were managed according to guidelines approved by the University of Florida Institute of Food and Agricultural Sciences Animal Research Committee.

\section{Animals, Housing, and Feeding}

Four ruminally cannulated lactating primiparous Holstein cows averaging (mean \pm SD) $284 \pm 18$ DIM, $32 \pm 3 \mathrm{~kg}$ of milk/d, and $634 \pm 45 \mathrm{~kg}$ of BW were assigned randomly to 1 of 4 treatment sequences in an experiment with a $4 \times 4$ Latin square design with four 21-d experimental periods. Cows were housed in an open-sided freestall barn with sand-bedded stalls $(1.14 \times 2.31 \times 1.22 \mathrm{~m})$. The experimental pens were equipped with 2 rows of fans ( 1 fan/6 linear $\mathrm{m}$ ) with low-pressure nozzles for cooling the cows. One row of fans faced the feed lane immediately above the feed bunk and the other row of fans faced the bedded stalls. Fans were activated when ambient temperature exceeded $21.1^{\circ} \mathrm{C}$. Daily temperature and relative humidity data were downloaded from the Florida Automated Weather Network (http://fawn.ifas.ufl.edu/). Temperature-humidity index (THI) was calculated using the formula $\mathrm{THI}=\mathrm{T}_{\mathrm{db}}-\left[0.55-(0.55 \times \mathrm{RH} / 100) \times\left(\mathrm{T}_{\mathrm{db}}-58\right)\right]$ (Buffington et al., 1981), where $\mathrm{T}_{\mathrm{db}}$ was the dry bulb temperature $\left({ }^{\circ} \mathrm{F}\right)$ and $\mathrm{RH}$ was the relative humidity. During the experiment, the temperature averaged $11^{\circ} \mathrm{C}$ and ranged from 0 to $21^{\circ} \mathrm{C}$, relative humidity averaged $81 \%$ and ranged from 44 to $98 \%$, and THI averaged 49 and ranged from 25 to 75 . Artificial light was provided daily by suspended fluorescent bulbs. Water was available at all times. Areas between the feed bunks and the freestalls were flushed twice daily to remove manure.

Each cow was assigned randomly to an individual feeding gate (Calan Broadbent feeding system, American Calan Inc., Northwood, NH). All cows were trained to eat from their specific Calan gate during a 7-d period before a 5 -d prestudy covariate period, during which all cows were fed the control diet and DMI and milk production were measured.

\section{Diets and Treatments}

The TMR (Table 1) was formulated to meet or exceed the caloric and MP requirements of cows produc- 
Table 1. Ingredient and chemical composition of the experimental $\operatorname{diet}(\%$ of diet DM)

\begin{tabular}{lc}
\hline Item & Value \\
\hline Ingredient, \% of diet DM & \\
Corn silage & 41.7 \\
Wet brewers grain & 7.60 \\
Corn grain & 13.3 \\
Dried citrus pulp & 10.9 \\
Soy hulls & 12.1 \\
Soybean meal (47\% CP) & 10.1 \\
Mineral and vitamin mix ${ }^{1}$ & 4.3 \\
Nutrient composition & \\
CP, \% & 16.6 \\
Starch, \% & 22.5 \\
ADF, \% & 23.8 \\
NDF, \% & 35.9 \\
Hemicellulose, \% & 12.1 \\
NE ${ }^{2}$ Mcal/kg & 1.65 \\
Calcium, \% $\%$ & 0.64 \\
Phosphorus, \% & 0.37 \\
Magnesium, \% & 0.32 \\
Potassium, \% & 1.35 \\
Sodium, \% & 0.51 \\
Iron, mg/kg & 261 \\
Zinc, mg/kg $/ \mathrm{kg}, \mathrm{kg}$ & 62 \\
Copper, mg/kg & 17 \\
Manganese, mg/kg & 37 \\
\hline Vitami mera minty
\end{tabular}

${ }^{1}$ Vitamin mineral mixture composition (as is): $30 \%$ ProvAAL-Lys \& Met (Perdue Agribusiness, Salisbury, MD), 28.5\% sodium bicarbonate, 13.0\% DCAD Plus (Arm and Hammer Animal Nutrition, Princeton, NJ), $9.0 \%$ calcium carbonate, $7.0 \%$ dicalcium phosphate, $7.0 \%$ magnesium oxide, $3.5 \%$ salt $(\mathrm{NaCl}), 1.2 \%$ Zinpro Availa-4 (Zinpro Corp., Eden Prairie, MN), 0.6\% Sel-Plex1000 (Alltech, Nicholasville, KY), $0.22 \%$ Rumensin90 (Elanco, Eli Lilly, Indianapolis, IN).

${ }^{2}$ Calculated according to NRC (2001) using feed values at 3 times maintenance.

ing at least $30 \mathrm{~kg}$ of milk (NRC, 2001) using CPMDairy version 3.0.10 software (www.cpmdairy.net). The grain mix, which included dry concentrate ingredients and soy hulls, was mixed weekly and stored in grain bins. The grain mix, wet brewers grains, and forage ingredients were mixed daily in a Calan data ranger (American Calan Inc.) before each feeding at 0700 and $1300 \mathrm{~h}$. Feed offered was adjusted daily to yield 5 to $10 \%$ of orts.

Treatments included the control with no yeast, a low dose $\left(5.7 \times 10^{7} \mathrm{cfu} /\right.$ cow per day) of live yeast (LLY), a high dose $\left(6.0 \times 10^{8} \mathrm{cfu} /\right.$ cow per day $)$ of live yeast $($ HLY $)$, and a high dose $\left(6.0 \times 10^{8} \mathrm{cfu} / \mathrm{cow}\right.$ per day before heat-induced inactivation of yeast cells) of killed yeast (HDY). Inactivation of the live yeast for the HDY treatment was achieved by heating in a water bath for $1.5 \mathrm{~h}$ at $80^{\circ} \mathrm{C}$ followed by freeze drying. Lack of viability was confirmed by plating on agar. The level of killed yeast supplemented was selected based on findings from a pre-experimental study in which ruminal $\mathrm{pH}$ was increased by supplementing the live yeast at $6.0 \times 10^{8} \mathrm{cfu} / \mathrm{cow}$ (http://www.google.com/patents/
US20130330439). Yeast additives were top dressed on respective TMR during both morning and afternoon feedings. The uniqueness of the new yeast strain (YE1496) examined was confirmed by mitochondrial DNA digestion of selected colonies with Haemophilus influenzae restriction enzyme (Hinf I; Roche Applied Science, Indianapolis, IN; Querol et al., 1992). Furthermore, its uniqueness is evident from its isolation from corn silage rather than crops or insects (http://www .google.com/patents/US20130330439) and the maintenance of its viability during ensiling (Duniere et al., 2015), such that it can potentially be applied as an inoculant at the time of ensiling rather than at feeding.

Yeast doses were selected to represent populations likely to be present in corn silage with moderate and high yeast counts at the time of feeding (Ward, 2011). This was done to examine effects yeast could have if they were added to corn forage at ensiling and dominated the epiphytic yeast population in the silage. Daily doses of yeast for each cow in each treatment were cultured on Baltimore Biological Laboratory agar, freeze dried, enumerated, and added to a maltodextrin carrier in individual plastic tubes that were stored at $4^{\circ} \mathrm{C}$ before being used.

\section{Intake Measurement and Diet Composition}

Feed offered and orts were measured and recorded daily to estimate feed intake. Approximately $200 \mathrm{~g}$ of orts was collected and retained for DM analysis (d 11-21). The DMI was determined as the difference between feed offered and orts on a DM basis. During each period, ingredient samples (corn silage, brewers grains, and grain mix) were collected (200 g) twice weekly, dried at $55^{\circ} \mathrm{C}$ for $48 \mathrm{~h}$ in a forced-air oven, and ground through the 1-mm screen of a Wiley mill (A. H. Thomas Co., Philadelphia, PA). All ingredient samples were composited to reconstitute the TMR at the end of each period. Each TMR sample was analyzed for DM, $\mathrm{CP}$, starch, NDF, ADF, ash, and minerals at Dairy One Laboratory (Ithaca, NY). Nitrogen was measured by rapid combustion using a Macro Elemental nitrogen analyzer (AOAC International, 2000; Vario MAX CN, model 25.00-5003; Elementar, Hanau, Germany). To calculate CP, the nitrogen value was multiplied by 6.25 . Concentrations of NDF and ADF were determined using the nonsequential method of Van Soest et al. (1991) in an Ankom A200 Fiber Analyzer (Ankom Technologies, Macedon, NY). Heat-stable $\alpha$-amylase was used in the NDF procedure, and the results were expressed exclusive of residual ash. Minerals (Ca, P, Mg, K, Na, $\mathrm{Fe}, \mathrm{Zn}, \mathrm{Cu}$, and $\mathrm{Mn}$ ) were analyzed using an inductively coupled plasma radical spectrometer (ICAP, Thermo Scientific, Waltham, MA) after microwave digestion. 


\section{Milk and Milk Composition}

Cows were milked twice daily at approximately 0900 and $2100 \mathrm{~h}$. Individual milk yields and concentrations of fat and true protein were recorded daily using the Afikim milking system (AfiLab Mini Laboratory, S.A.E. Afikim, Israel). Final concentrations of milk components were calculated based on milk production during morning and evening milkings. The $3.5 \% \mathrm{FCM}$ yields were calculated based on the equation $[0.4324 \times$ milk yield $(\mathrm{kg} / \mathrm{d})]+[16.218 \times$ milk fat yield $(\mathrm{kg} / \mathrm{d})]$ (NRC, 2001). Daily milk and milk component yields and concentrations from d 11 to 21 of each period were used for statistical analysis.

\section{Apparent Total-Tract Digestibility}

Chromic oxide was used as a marker for determination of total-tract in vivo apparent DM, NDF, ADF, and starch digestibility (Schneider and Flatt, 1975). Chromic oxide was weighed $(10 \mathrm{~g})$ into gelatin capsules and orally dosed twice daily at 0600 and $1800 \mathrm{~h}$ for 10 d (d 12-21). Fecal samples were collected by rectal sampling during the last $5 \mathrm{~d}$ of dosing (d 17-21) of each period. Fecal samples from individual cows were composited across days, dried in a forced-air oven at $55^{\circ} \mathrm{C}$ to constant weight, and ground through a 1-mm screen of a Wiley mill (A. H. Thomas). Concentrations of fecal chromium were measured using an atomic absorption spectrometer (model 5000, Perkin Elmer, Wellesley, MA) according to the procedure described by Williams et al. (1962). Fecal NDF and ADF concentrations were sequentially determined as described earlier. Fecal hemicellulose concentration was calculated as the difference between NDF and ADF concentrations. Fecal starch was determined by near-infrared reflectance spectroscopy at Dairy One Laboratory.

\section{Blood Glucose and Urea Nitrogen}

Blood samples were collected before the morning feeding on d 21 of each period via coccygeal venipuncture into sodium heparin vacutainer tubes containing anticoagulant. Blood samples were centrifuged at 2,500 $\times g$ at $4^{\circ} \mathrm{C}$ for $20 \mathrm{~min}$, and plasma was collected and frozen $\left(-20^{\circ} \mathrm{C}\right)$ for later analysis of glucose and urea nitrogen. Plasma glucose and urea were determined using an autoanalyzer by adaptations of Bran and Luebbe industrial methods no. 339-19 (Gochman and Schmitz, 1972) and 339-01 (Marsh et al., 1965), respectively (Technicon Instruments Corp., Chauncey, NY), and the analytes were quantified colorimetrically.

\section{Ruminal Fluid VFA and Ammonia Nitrogen}

Ruminal fluid samples collected via a ruminal cannula at $0,2,4,6,8$, and $10 \mathrm{~h}$ after the morning feeding on d 21 of each period were used for analyzing VFA and ammonia nitrogen concentrations. Immediately after collection, ruminal fluid samples were strained through 4 layers of cheesecloth; $12 \mu \mathrm{L}$ of $50 \% \mathrm{H}_{2} \mathrm{SO}_{4}$ were added to $12 \mathrm{~mL}$ of ruminal fluid, and the mixture was centrifuged at $11,500 \times g$ for $20 \mathrm{~min}$. The supernatant was stored at $-20^{\circ} \mathrm{C}$ until analyzed for lactate and VFA (Muck and Dickerson, 1988) using an HPLC (FL 7485, Hitachi, Tokyo, Japan) connected to a UV detector (Spectroflow 757, ABI Analytical Kratos Division, Ramsey, NJ) set at $210 \mathrm{~nm}$. The column (Aminex HPX-87H, Bio-Rad Laboratories, Hercules, CA) had a $0.015 \mathrm{M} \mathrm{H}_{2} \mathrm{SO}_{4}$ mobile phase and a flow rate of 0.7 $\mathrm{mL} / \mathrm{min}$ at $45^{\circ} \mathrm{C}$. Ammonia nitrogen was measured using an adaptation of the Noel and Hambleton (1976) procedure for an autoanalyzer (Technicon, Tarrytown, NY) that quantifies nitrogen colorimetrically.

\section{Ruminal $\mathrm{pH}$ and Temperature}

Indwelling probes (Dascor T7 monitoring boluses, Dascor Inc., Escondido, CA), set to record $\mathrm{pH}$ and temperature every $15 \mathrm{~min}$, were placed in the rumen of cows for the last $5 \mathrm{~d}$ of the covariate period and during $\mathrm{d} 1$ to 21 of each period. The $\mathrm{pH}$ probes were calibrated before insertion in the rumen before each period. The $\mathrm{pH}$ and temperature data acquired were downloaded, and $\mathrm{pH}$ data were corrected for drift following the manufacturer's guidelines.

\section{Ruminal Sampling and Sequencing of Dominant Bacteria}

Rumen contents were collected from all 4 cows at 0 , $2,4,6,8$, and $10 \mathrm{~h}$ after the morning feeding on $\mathrm{d} 21$ of each period. Rumen contents were separated into liquid and solid fractions using 4 layers of cheesecloth and stored at $-80^{\circ} \mathrm{C}$ for DNA extraction. The methods for total genomic DNA extraction, sequencing, and sequence analysis, including operational taxonomic unit classification with the GreenGenes database, were previously described in a companion paper (Jiang et al., 2017).

\section{Statistical Analysis}

The experimental design was a Latin square with 4 replicate animals and periods. Data were analyzed using the GLIMMIX procedure of SAS version 9.3 
(SAS Institute, Cary, NC). The model for analyzing outcomes that were not measured repeatedly over time (nutrient digestibility and digestible nutrient intakes) had the form

$$
Y=\mu+T_{i}+P_{j}+C_{k}+\varepsilon_{i j k},
$$

where $\mu$ is the overall mean, $T_{i}$ is the treatment effect, $P_{j}$ is the period effect, $C_{k}$ is the cow effect (random), and $\varepsilon_{i j k}$ is the residual error.

The model for analyzing DMI, milk yield, and components that were measured repeatedly over time on the same experimental unit had the form

$$
\begin{aligned}
Y=\mu & +T_{i}+P_{j}+C_{k}+C V_{l}+D_{m} \\
& +(T \times D)_{i m}+\varepsilon_{i j k l m},
\end{aligned}
$$

where $\mu$ is the overall mean, $T_{i}$ is the treatment effect, $P_{j}$ is the period effect, $C_{k}$ is the cow effect (random), $C V_{l}$ is the covariate effect, $D_{m}$ is the day effect, $(T \times$ $D)_{i m}$ is the interaction between treatment and day, and $\varepsilon_{i j k l m}$ is the residual error.

The model for analyzing ruminal fermentation data measured repeatedly over time on the same experimental unit had the form

$$
\begin{aligned}
Y=\mu & +T_{i}+P_{j}+C_{k}+C V_{l}+T H_{m} \\
& +(T \times T H)_{i m}+\varepsilon_{i j k l m},
\end{aligned}
$$

where $\mu$ is the overall mean, $T_{i}$ is the treatment effect, $P_{j}$ is the period effect, $C_{k}$ is the cow effect (random), $C V_{l}$ is the covariate effect, $T H_{m}$ is the effect of sampling time, $(T \times T H)_{i m}$ is the interaction between treatment and time, and $\varepsilon_{i j k l m}$ is the residual error.

Normality was tested by examining the distribution of residuals. Denominator degrees of freedom were estimated using the Kenward-Roger method in the MODEL statement. Time was used in the repeated measures statement with autoregressive order 1 as the repeated-measures covariance structure based on the experimental design and treatment structure (Kincaid, 2005) and because it gave the smallest Akaike information criterion values. Intake, milk production, ruminal $\mathrm{pH}, \mathrm{VFA}$, ammonia, and plasma urea and glucose data were covariate adjusted. Preplanned nonorthogonal contrasts that were examined to compare least squares means included the following: control versus LLY (effect of adding LLY), control versus HLY (effect of adding HLY), LLY versus HLY (effect of the dose of live yeast), average of LLY and HLY versus HDY (mean effect of adding live versus killed yeast), and control versus HDY (effect of adding killed yeast). For simplic- ity, we refer to contrast LLY + HLY versus HDY as the viability effect in the rest of the article, though we acknowledge that it would have been more accurate to ascertain viability effects at each dose. Treatment effects and their interactions were declared significant at $P \leq 0.05$, and tendencies for significance were declared at $0.05<P \leq 0.10$.

Pearson correlation analysis was used to examine the association between the RA of dominant ruminal bacteria (RA $>0.5 \%)$ and nutrient digestibility (DM, NDF, ADF, hemicellulose, and starch) or performance parameters (DMI, milk yield, milk fat and milk protein concentration, and feed efficiency). The Pearson correlation coefficients were generated using $\mathrm{R}$ software (http://www.r-project.org). Pearson correlations were declared significant at $P \leq 0.5$, whereas tendencies were declared at $0.05<P \leq 0.10$.

\section{RESULTS}

Dry matter intake was unaffected $(P>0.10)$ by dietary treatments and averaged $25.3 \pm 0.64 \mathrm{~kg} / \mathrm{d}$ (Table 2 ). Adding LLY to the diet increased both milk yield $(P=0.04)$ and $3.5 \%$ FCM yield $(P=0.05)$ by about $2 \mathrm{~kg} / \mathrm{d}$. Adding LLY also increased $(P=0.04)$ milk protein yield by $0.08 \mathrm{~kg} / \mathrm{d}$ and tended to increase $(P$ $=0.07)$ milk fat yield by $0.07 \mathrm{~kg} / \mathrm{d}$. However, adding HLY did not affect milk yield $(P=0.73)$ or milk fat or protein concentration or yield $(P>0.10)$. Adding LLY tended to increase milk yield $(P=0.09), 3.5 \%$ FCM yield $(P=0.08)$, and milk fat yield $(P=0.10)$ compared with HLY. Milk fat and protein concentrations were not different among treatments $(P>0.10)$. In contrast, HDY had no effect on DMI, milk yield, and milk composition $(P>0.10)$ compared with the control treatment or live yeast supplementation.

Adding LLY to the diet increased in vivo apparent digestibility of $\mathrm{DM}(P=0.03)$, NDF $(P=0.01), \mathrm{ADF}$ $(P=0.01)$, and hemicellulose $(P=0.01$; Table 3$)$ by $4.6,9.5,7.8$, and 12.9 percentage units, respectively. Supplementing the diet with HLY also improved digestibility of $\mathrm{DM}(P=0.04), \mathrm{NDF}(P=0.02), \operatorname{ADF}(P$ $=0.02)$, and hemicellulose $(P=0.03)$ compared with the control. However, no improvements in digestibility parameters were detected by increasing the dose of live yeast (HLY vs. LLY). Adding HDY tended to increase NDF $(P=0.07)$, ADF $(P=0.07)$, and hemicellulose digestibility $(P=0.10)$ by $5.7,4.6$, and 7.5 percentage units, respectively, compared with the control. Adding live yeast instead of killed yeast increased DM digestibility $(P=0.03)$ by 4.1 percentage units. Adding LLY to the diet also tended to increase $(P=0.10)$ digestible intake of ADF and increased digestible intake of hemi- 
cellulose $(P=0.02)$ by 0.55 and $0.41 \mathrm{~kg} / \mathrm{d}$, respectively, compared with the control. Supplementing with HLY tended to increase digestible intake of DM $(P=0.08)$ and $\operatorname{ADF}(P=0.10)$ and increased digestible hemicellulose intake $(P=0.05)$ compared with the control. Adding live yeast instead of HDY tended to increase $(P=0.09)$ digestible DMI by $1.5 \mathrm{~kg} / \mathrm{d}$. Yeast supplementation had no effects on starch or CP digestibility irrespective of the dose and viability $(P>0.10)$

Yeast supplementation had no effects on minimum, maximum, and mean ruminal $\mathrm{pH}(P>0.10$; Figure 1). Similarly, no effects on ruminal temperature were observed with yeast supplementation (Figure 2) except for a tendency to increase maximum ruminal temperature with HLY $(P=0.08)$ when compared with the control or LLY.

Total ruminal VFA concentration was unaffected by dietary treatment $(P>0.10$; Table 4$)$. Acetate: propionate ratio and acetate + butyrate:propionate ratio tended to increase with LLY $(P=0.09$ and 0.11 , respectively) or HLY ( $P=0.09$ and 0.11 , respectively) supplementation (Table 4), whereas substituting HDY for live yeast increased $(P=0.02)$ the molar proportion of valerate. Addition of HDY to the diet (HDY vs. control) also increased $(P=0.03)$ the molar proportion of valerate and tended to increase $(P=0.07)$ lactate concentration. No difference in molar proportions of acetate, propionate, butyrate, isobutyrate, and isovalerate was observed among treatments $(P>0.10)$. Ruminal ammonia nitrogen $\left(\mathrm{NH}_{3}-\mathrm{N}\right)$, plasma glucose, and urea nitrogen concentrations were not affected by dietary treatments $(P>0.10)$.

\section{Correlation Between Performance Measurements and Dominant Bacteria Identified from the Solid Fraction of Ruminal Contents}

Figure 3 shows a heat map that summarizes associations between animal performance measurements and bacteria RA in the solid fraction of rumen contents. The respective correlation coefficients are shown in Table 5. Digestibility of DM correlated negatively with RA of unclassified Lachnospiraceae $(\mathrm{r}=-0.50 ; P=$ $0.05)$ and unclassified RFP12 $(\mathrm{r}=-0.43 ; P=0.10)$. Likewise, digestibility of NDF correlated negatively with RA of unclassified Lachnospiraceae ( $\mathrm{r}=-0.52 ; P$ $=0.04)$ and unclassified RFP12 $(\mathrm{r}=-0.65 ; P<0.01)$. Digestibility of ADF correlated positively with RA of Ruminococcus ( $\mathrm{r}=0.44 ; P=0.09)$ and unclassified Succinivibrionaceae $(\mathrm{r}=0.69 ; P<0.01)$ and negatively with RA of Prevotella $(\mathrm{r}=-0.57 ; P=0.02)$, YRC22 $(\mathrm{r}$ $=-0.44 ; P=0.09)$, unclassified S24-7 $(\mathrm{r}=-0.57 ; P=$ $0.02)$, and unclassified RFP12 $(\mathrm{r}=-0.45 ; P=0.08)$. Starch digestibility correlated negatively with RA of 
unclassified Lachnospiraceae $(\mathrm{r}=-0.53 ; P=0.03)$ and RFP12 ( $\mathrm{r}=-0.63 ; P<0.01)$.

Dry matter intake correlated positively with RA of unclassified Succinivibrionaceae $(\mathrm{r}=0.52 ; P=0.04)$ and unclassified Bacteroidales $(\mathrm{r}=0.47 ; P=0.07)$ and negatively with both Prevotella $(\mathrm{r}=-0.45 ; P=0.08)$ and Bifidobacterium $(\mathrm{r}=-0.46 ; P=0.07)$. Milk yield correlated positively with Lachnospiraceae [Ruminococcus $](\mathrm{r}=0.43 ; P=0.10)$ and negatively with RA of Fibrobacter $(\mathrm{r}=-0.44 ; P=0.08)$, Clostridium $(\mathrm{r}=$ $-0.64 ; P<0.01)$, and CF231 $(\mathrm{r}=-0.48 ; P=0.06)$. Milk fat concentration correlated positively with RA of Fibrobacter ( $\mathrm{r}=0.60 ; P=0.01)$, Ruminobacter $(\mathrm{r}$ $=0.46 ; P=0.07)$, and unclassified Bacteroidales $(\mathrm{r}=$ $0.65 ; P<0.01)$ and negatively with RA of Prevotella $(\mathrm{r}=-0.43 ; P=0.09)$, Butyrivibrio $(\mathrm{r}=-0.43 ; P=$ $0.10)$, Bifidobacterium $(\mathrm{r}=-0.53 ; P=0.04)$, unclassified Paraprevotellaceae ( $\mathrm{r}=-0.56 ; P=0.02)$, and Lachnospiraceae $[$ Ruminococcus $](\mathrm{r}=-0.47 ; P=0.06)$. Milk protein concentration correlated positively with RA of Fibrobacter $(\mathrm{r}=0.49 ; P=0.05)$, Ruminobacter $(\mathrm{r}=0.44 ; P=0.09)$, Clostridium $(\mathrm{r}=0.47 ; P=0.06)$, unclassified Bacteroidales ( $\mathrm{r}=0.58 ; P=0.02)$, and unclassified Lachnospiraceae ( $\mathrm{r}=0.44 ; P=0.09)$ and negatively with RA of unclassified Paraprevotellaceae $(\mathrm{r}=-0.52 ; P=0.04)$. Feed efficiency correlated positively with RA of unclassified Bacteroidales ( $\mathrm{r}=0.48$; $P=0.06)$, unclassified Lachnospiraceae $(\mathrm{r}=0.63 ; P$ $<0.01)$, and unclassified RFP12 $(\mathrm{r}=0.56 ; P=0.02)$ and negatively with RA of Treponema $(\mathrm{r}=-0.44 ; P=$ $0.09)$ and unclassified Paraprevotellaceae $(\mathrm{r}=-0.50 ; P$ $=0.05)$.

\section{Correlation Between Performance Measurements and Dominant Bacteria Identified from the Liquid Fraction of Ruminal Contents}

Figure 4 shows a heat map that summarizes associations between animal performance measurements and bacteria RA in the liquid fraction of rumen contents. The respective correlation coefficients and probabilities are shown in Table 6. Digestibility of DM correlated negatively with RA of Ruminobacter $(\mathrm{r}=-0.57 ; P=$ $0.02)$ and unclassified Lachnospiraceae $(\mathrm{r}=-0.56 ; P=$ $0.02)$, as did that for digestibility of NDF ( $\mathrm{r}=-0.57 ; P$ $=0.02$ ). Digestibility of ADF correlated positively with $\mathrm{RA}$ of unclassified Succinivibrionaceae $(\mathrm{r}=0.52 ; P=$ 0.04 ) and negatively with RA of unclassified Lachnospiraceae $(\mathrm{r}=-0.75 ; P<0.01)$, as did starch digestibility $(\mathrm{r}=-0.44 ; P=0.09)$.

Dry matter intake correlated positively with RA of Ruminococcus $(\mathrm{r}=0.52 ; P=0.04)$, Fibrobacter $(\mathrm{r}=$ $0.47 ; P=0.07)$, unclassified Succinivibrionaceae ( $\mathrm{r}=$ $0.63 ; P<0.01)$, and unclassified Bacteroidales $(\mathrm{r}=$ 


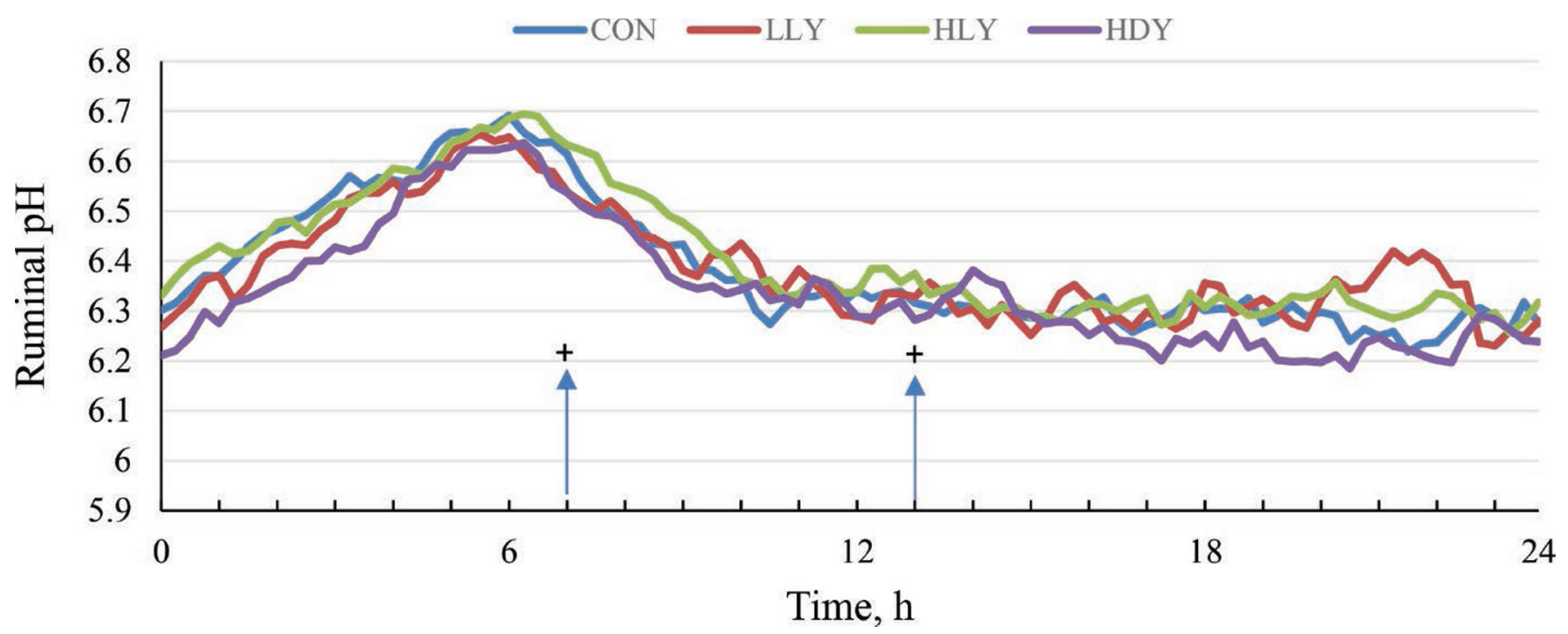

Figure 1. Effect of dietary addition of 2 doses of live yeast or 1 dose of killed yeast on the diurnal variation in the ruminal $\mathrm{pH}$ of lactating dairy cows. $\mathrm{CON}=$ no Saccharomyces cerevisiae supplementation; LLY $=$ low daily dose $\left(5.7 \times 10^{7}\right.$ cfu/cow $)$ of live S. cerevisiae YE1496 (DuPont Pioneer, Johnston, IA); HLY = high daily dose $\left(6.0 \times 10^{8} \mathrm{cfu} / \mathrm{cow}\right)$ of live S. cerevisiae YE1496 (DuPont Pioneer); HDY = high daily dose $\left(6.0 \times 10^{8} \mathrm{cfu} / \mathrm{cow}\right)$ of killed $S$. cerevisiae YE1496 (DuPont Pioneer; yeasts were killed by heating in a water bath for $1.5 \mathrm{~h}$ at $80^{\circ} \mathrm{C}$ ). Cows were fed at 0700 and $1300 \mathrm{~h}(\mathrm{~h} 7$ and 13 in the figure; indicated by + ). The SEM value for treatment was 0.03 . Mean pH values for CON, LLY, HLY, and HDY were 6.41, 6.42, 6.42, and 6.35, respectively $(\mathrm{SEM}=0.15)$. Color version available online.

$0.72 ; P<0.01)$ and negatively with RA of Prevotella $(\mathrm{r}=-0.64 ; P<0.01)$. Milk yield correlated positively with RA of unclassified Paraprevotellaceae ( $\mathrm{r}=0.49$;
$P=0.05)$ and negatively with CF231 $(\mathrm{r}=-0.71 ; P<$ $0.01)$ and unclassified Porphyromonadaceae $(\mathrm{r}=-0.70$ $P<0.01)$. Milk fat concentration correlated positively

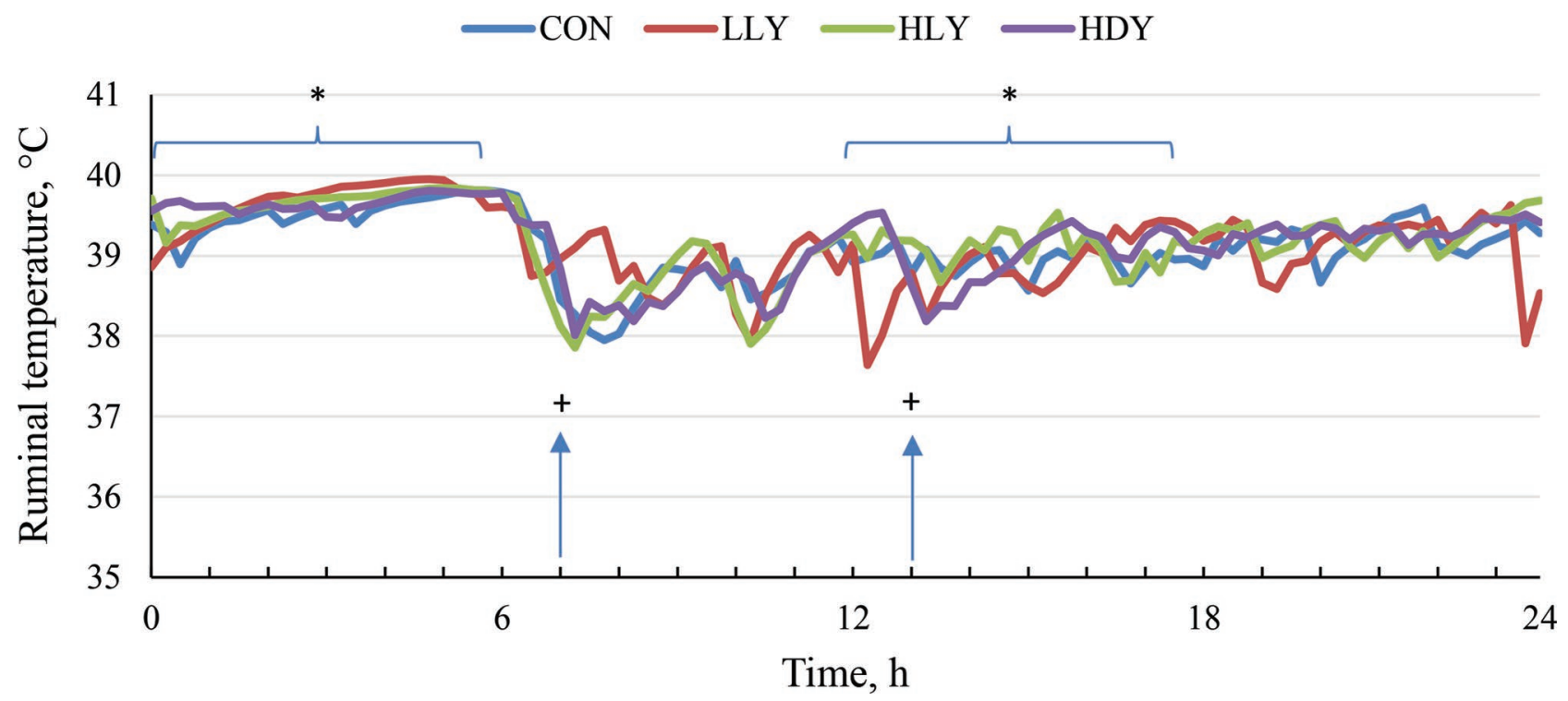

Figure 2. Effect of dietary addition of 2 doses of live yeast or 1 dose of killed yeast on the diurnal variation in the ruminal temperature $\left({ }^{\circ} \mathrm{C}\right)$ of lactating dairy cows. CON = no Saccharomyces cerevisiae supplementation; LLY = low daily dose $\left(5.7 \times 10^{7}\right.$ cfu/cow $)$ of live $S$. cerevisiae YE1496 (DuPont Pioneer, Johnston, IA); HLY = high daily dose $\left(6.0 \times 10^{8} \mathrm{cfu} / \mathrm{cow}\right)$ of live S. cerevisiae YE1496 (DuPont Pioneer); HDY $=$ high daily dose $\left(6.0 \times 10^{8} \mathrm{cfu} / \mathrm{cow}\right)$ of killed $S$. cerevisiae YE1496 (DuPont Pioneer; yeasts were killed by heating in a water bath for $1.5 \mathrm{~h}$ at $\left.80^{\circ} \mathrm{C}\right)$. Cows were fed at 0700 and $1300 \mathrm{~h}\left(\mathrm{~h} 7\right.$ and 13 in the figure; indicated by + ). The SEM value for treatment was 0.06 . ${ }^{*}$ Treatment $\times$ time interactions were significant at 0 to $6 \mathrm{~h}(P=0.003)$ and 12 to $18 \mathrm{~h}(P=0.01)$. Mean temperature for CON, LLY, HLY, and HDY was $39.1,39.1,39.3$, and $39.2^{\circ} \mathrm{C}$, respectively ( $\mathrm{SEM}=0.15$ ). Maximum temperature for CON, LLY, HLY, and HDY was $40.2,40.2,40.5$, and $40.4^{\circ} \mathrm{C}$, respectively $(\mathrm{SEM}=0.13$; control vs. HLY, $P=0.08$; LLY vs. HLY, $P=0.08$ ). Color version available online. 
with RA of Ruminococcus ( $\mathrm{r}=0.46 ; P=0.07$ ), Fibrobacter $(\mathrm{r}=0.71 ; P<0.01)$, CF231 $(\mathrm{r}=0.72 ; P<0.01)$, unclassified Bacteroidales $(\mathrm{r}=0.71 ; P<0.01)$, and unclassified Porphyromonadaceae $(\mathrm{r}=0.50 ; P<0.05)$ and negatively with Prevotella $(\mathrm{r}=-0.59 ; P=0.02)$ and unclassified Paraprevotellaceae $(\mathrm{r}=-0.55 ; P=$ 0.03). Milk protein concentration correlated positively with RA of Fibrobacter ( $\mathrm{r}=0.61 ; P=0.01)$, CF231 ( $\mathrm{r}$ $=0.67 ; P<0.01)$, unclassified Bacteroidales $(\mathrm{r}=0.53$; $P=0.03)$, and unclassified Porphyromonadaceae $(\mathrm{r}=$ $0.66 ; P<0.01)$ and negatively with RA of Prevotella ( $\mathrm{r}=-0.53 ; P=0.03)$ and unclassified Paraprevotellaceae $(\mathrm{r}=-0.53 ; P=0.03)$. Feed efficiency correlated positively with RA of Fibrobacter $(\mathrm{r}=0.59 ; P=0.02)$, Ruminobacter $(\mathrm{r}=0.45 ; P=0.08), \mathrm{CF} 231(\mathrm{r}=0.51$; $P=0.04)$, and unclassified Porphyromonadaceae $(\mathrm{r}=$ 0.66; $P<0.01)$ and negatively with RA of Prevotella $(\mathrm{r}$ $=-0.50 ; P=0.05)$ and unclassified Veillonellaceae $(\mathrm{r}$ $=-0.49 ; P=0.05)$.

\section{DISCUSSION}

Yeast supplementation had no effects on DMI, which agrees with previous studies on live yeast (Bach et al., 2007; Ferraretto et al., 2012; DeVries and Chevaux, 2014). However, meta-analytical and literature summaries of existing studies suggest that the DMI response to yeast supplementation is inconclusive. Desnoyers et al. (2009) reported that live yeast supplementation increased DMI by $0.44 \mathrm{~g} / \mathrm{kg}$ of BW, but no effects on DMI were detected by supplemental dietary yeast cultures (Poppy et al., 2012) or with live and dead yeast culture products (Robinson and Erasmus, 2009). Several factors may explain the contradictory responses to feeding yeast, including stage of lactation (Wohlt et al., 1998; Dann et al., 2000); level and type of stress faced by cows (Arambel and Kent, 1990; Wohlt et al., 1991); diet composition (Roa et al., 1997); yeast species (Mwenya et al., 2005; Moallem et al., 2009), strain (Newbold et al., 1996), viability (Lynch and Martin, 2002), and dose (Ferraretto et al., 2012); and the prevailing management or experimental conditions (Robinson, 2002). For instance, the average temperature in the present study was lower than that in several previous studies conducted during summer (Moallem et al., 2009). Moreover, whereas other studies involved acidotic diets (Bach et al., 2007), nonacidotic diets were used in this study, as shown by low starch level (22.5\%) and high minimum ruminal $\mathrm{pH}$ values $(>5.8)$.

The increased milk yield in response to LLY agrees with various meta-analytical summaries of the literature. Desnoyers et al. (2009) examined 110 studies on $S$. cerevisiae-based live yeast supplementation and reported that milk yield was increased by an average of 


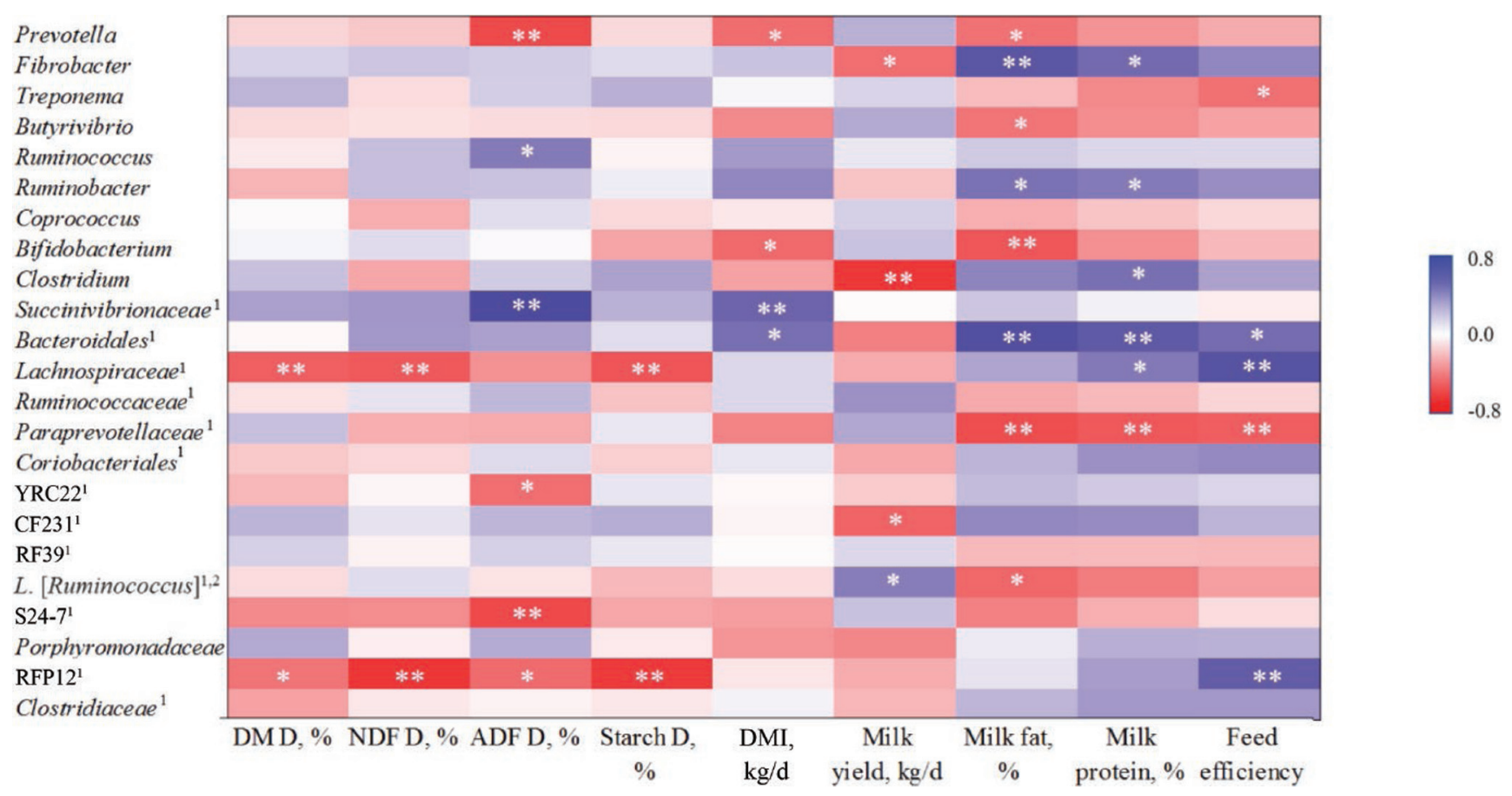

Figure 3. Pearson correlation between animal performance measurements and relative abundance of dominant bacteria $(>0.5 \%$ of the bacterial population) in the solid fraction of rumen contents. Feed efficiency was calculated by dividing $3.5 \%$ FCM by DMI. D = digestibility ${ }^{1}$ Unclassified members in the respective family or order. ${ }^{2}$ The genus in parentheses is incompletely classified. ${ }^{*}$ Pearson correlation coefficient tended to be significant $(0.05<P \leq 0.10)$. ${ }^{* *}$ Significant Pearson correlation coefficient $(P \leq 0.05)$. The abundance of bacteria and measurements of animal performance were averaged for each treatment at each period. Color version available online.

$1.2 \mathrm{~g} / \mathrm{kg}$ of BW. de Ondarza et al. (2010) summarized 14 studies and reported that $3.5 \%$ FCM was increased by $1.13 \mathrm{~kg} / \mathrm{d}$ with live yeast supplementation. Milk yield responses to live yeast supplementation may be attributable to improved fiber digestion due to an oxygen scavenging effect by viable yeast, thus reducing the redox potential in the rumen and thereby favoring the growth of oxygen-sensitive anaerobic ruminal bacteria (Newbold et al., 1996; Chaucheyras-Durand and Fonty, 2002). The fact that LLY or HLY supplementation improved NDF and ADF digestion is consistent with previous studies demonstrating that yeast supplementation increased NDF (Marden et al., 2008; Ferraretto et al., 2012) and ADF (Marden et al., 2008) digestibility. The lack of effects of LLY and HLY on CP and starch digestibility also agrees with previous studies (Moallem et al., 2009; Ferraretto et al., 2012), indicating that the increase in DM digestibility associated with LLY and HLY was primarily attributable to increased fiber digestion. As mentioned earlier, effects on fiber digestion are probably attributed to the stimulatory effect of yeast on cellulolytic bacteria. The companion study (Jiang et al., 2017) and other studies (Callaway and Martin, 1997; Pinloche et al., 2013) have demonstrated that the RA of the main ruminal cellulolytic bacteria
(Fibrobacter succinogenes, Ruminococcus albus, and $R$. flavefaciens) increased when LLY was added to the diet or when live yeast was substituted for killed yeast.

No effects were observed on milk yield in response to HLY. It is not clear why the higher yeast dose (HLY) did not increase milk production when the lower dose (LLY) did relative to the control treatment. A previous study detected no effects of live yeast dose $\left(3 \times 10^{9}\right.$ or $6 \times 10^{10} \mathrm{cfu} /$ cow per day) on milk yield (Ferraretto et al., 2012). Elghandour et al. (2014) noted that increasing the dose of a live yeast culture $\left(1 \times 10^{10} \mathrm{cfu}\right.$ of live yeast cells/g of yeast culture product) did not increase in vitro DM degradability of low-quality roughages. As in these studies, our study showed that the high yeast dose was not more effective than the low dose. However, unlike the latter study, our study also showed that the low dose of live yeast was more effective than the high dose at improving milk production, which is attributable at least partly to changes in the rumen microbiome reported in our companion study (Jiang et al., 2017). The high dose of live yeast reduced the abundance of Butyrivibrio fibrisolvens, a secondary cellulolytic species (Weimer, 1996), but HLY did not affect primary and predominant cellulolytic species such as $R$. albus, $R$. flavefaciens, or F. succinogenes (Miron et al., 2001). 
JIANG ET AL.

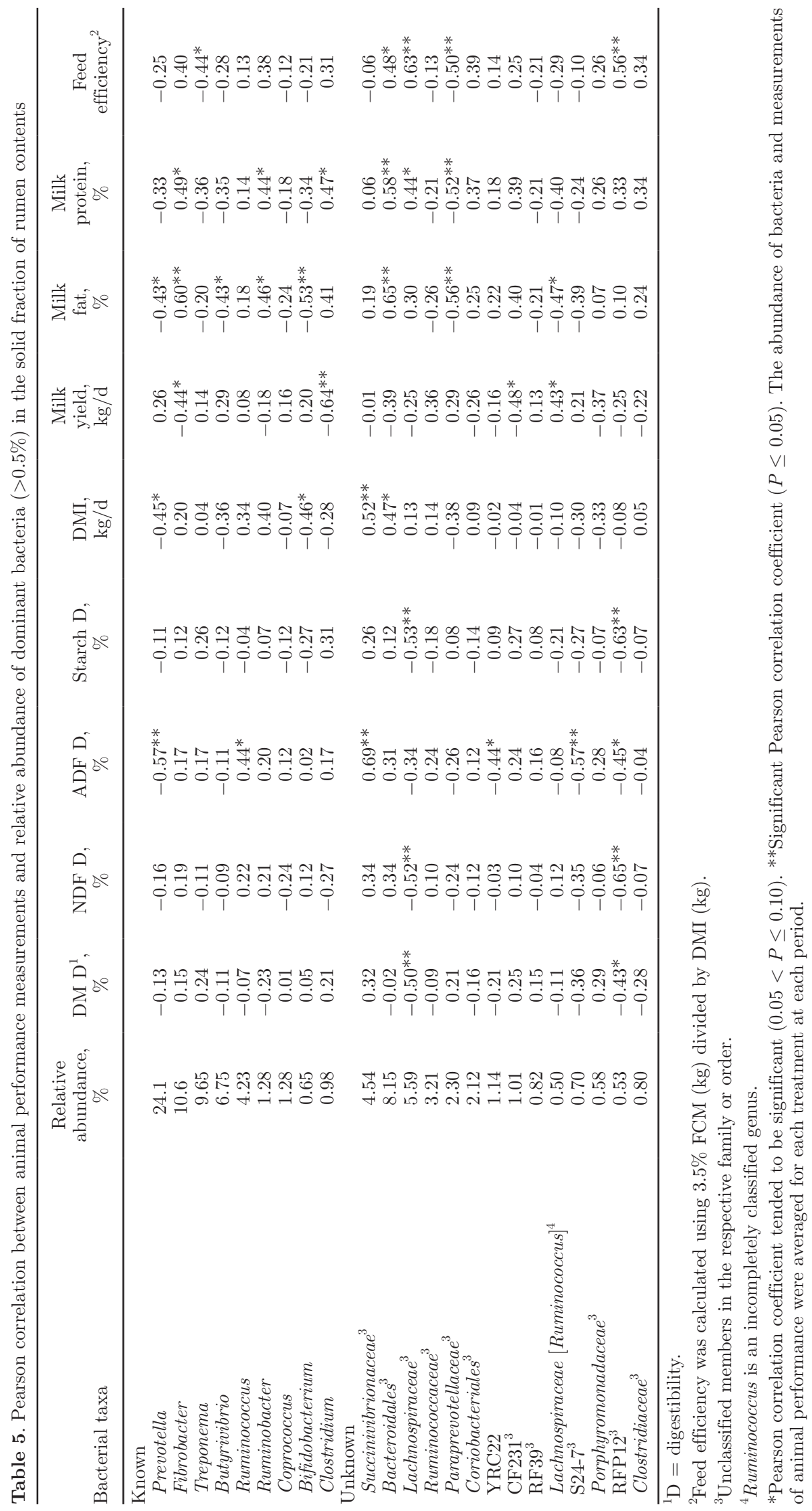




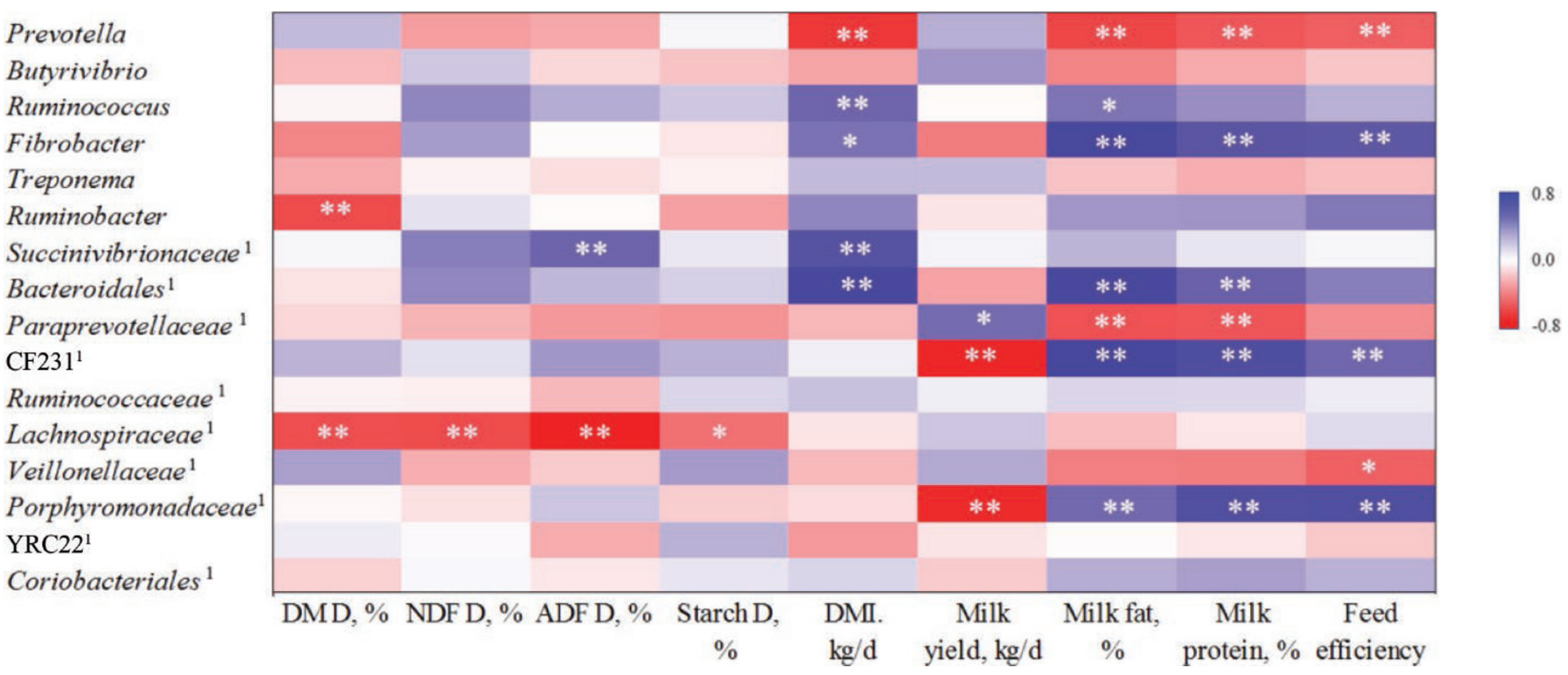

Figure 4. Pearson correlation between animal performance measurements and relative abundance of dominant bacteria ( $>0.5 \%)$ in the liquid fraction of rumen contents. Feed efficiency was calculated by dividing $3.5 \%$ FCM by DMI. D = digestibility. ${ }^{1}$ Unclassified members in the respective family or order. ${ }^{*}$ Pearson correlation coefficient tended to be significant $(0.05<P \leq 0.10)$. ${ }^{*}$ Significant Pearson correlation coefficient $(P$ $\leq 0.05)$. The abundance of bacteria and measurements of animal performance were averaged for each treatment at each period. Color version available online.

The RA of CF231 was reduced in the solid fraction of rumen contents as the dose of live yeast increased (Jiang et al., 2017), and CF231 was negatively correlated with milk yield. However, reduced abundance of CF231 with HLY might not have influenced milk production because its relative abundance in the ruminal solid fraction was low $(<2 \%)$. Future research should determine the role of these microbes in the mode of action of yeast in cows. In addition, cows used in the present study were in late lactation and produced relatively low quantities of milk; therefore, future studies should examine whether stage of lactation (Wohlt et al., 1998; Dann et al., 2000) alters the responses to yeast supplementation reported in this study.

Adding HDY to the diet tended to increase the digestibility of $\mathrm{NDF}$ and $\mathrm{ADF}$, and the results are consistent with the reported effects of supplemental killed yeast in lambs (Ghoneem and Mahmoud, 2014). In our companion study (Jiang et al., 2017), dietary addition of HDY increased the abundance of the cellulolytic genus Fibrobacter (Bryant, 1954) in the liquid fraction of the ruminal contents and tended to increase $\mathrm{NDF}$ and ADF digestibility in this study, probably via stimulation of cellulolytic bacteria by metabolites in the yeast culture medium (Callaway and Martin, 1997). Furthermore, the reduction of Lachnospiraceae in both the solid and liquid fraction by HDY may also partly explain the increase in NDF and ADF digestibility because Lachnospiraceae was negatively correlated with
NDF digestibility in both ruminal fractions. With HDY supplementation, the RA of Paraprevotellaceae in the liquid fraction of rumen contents decreased, whereas abundance of Porphyromonadaceae was increased. In the liquid fraction, Paraprevotellaceae had a positive correlation and Porphyromonadaceae had a negative correlation with milk yield. These results may explain why HDY tended to increase NDF and ADF digestibility without improving milk production. That HDY supplementation did not increase milk production may be partly attributable to the high dose, because the low dose of live yeast increased milk production, or to the ability of live yeast but not killed yeast to scavenge ruminal oxygen and thereby improve the redox potential of the rumen and activity of anaerobic bacteria (Chaucheyras-Durand and Fonty, 2002). Future studies should investigate whether a low dose of killed yeast will increase both fiber digestibility and milk production to ascertain the importance of yeast viability in the response.

The absence of treatment effects on ruminal $\mathrm{pH}$ is attributable to the lack of total VFA or ammonia nitrogen concentration responses to yeast supplementation. Although HDY tended to increase the lactate concentration in the rumen, ruminal $\mathrm{pH}$ was not affected, possibly because levels of ruminal lactate were very low. The ruminal $\mathrm{pH}$ response in this study contrasts with findings from previous studies in which live yeast supplementation increased ruminal $\mathrm{pH}$ (Guedes et al., 
JIANG ET AL.

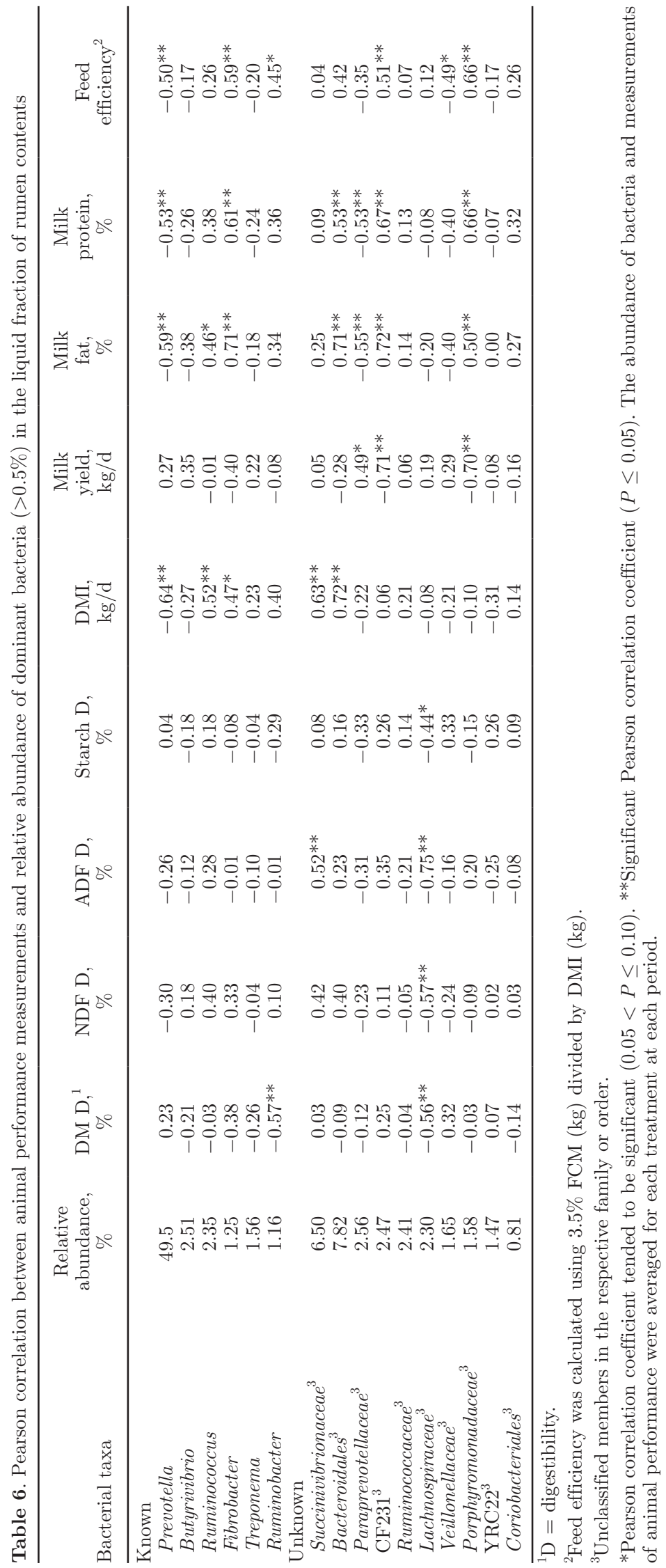


2008; Vyas et al., 2014) but agrees with the findings of García et al. (2000). Bach et al. (2007) also reported that live yeast decreased the duration that ruminal $\mathrm{pH}$ remains under critical thresholds of 5.6 and 6.0 (Bach et al., 2007). This suggests that yeast supplementation may be more effective at increasing the $\mathrm{pH}$ when acidotic diets are fed or when experimental conditions predispose to a low ruminal $\mathrm{pH}$. In this study, milk production was increased by LLY even though ruminal $\mathrm{pH}$ consistently remained above 5.8 . This is partly because high-forage diets were fed (forage:concentrate ratio $=$ 54:46), which probably explains the lack of ruminal $\mathrm{pH}$ responses to yeast supplementation.

For unknown reasons, the maximum ruminal temperature tended to be greater for cows fed HLY instead of the control or LLY. However, the increase was small and is probably not biologically significant because other measures of ruminal temperature were not affected by dietary treatments in this study. Temporary drops in ruminal temperature in response to LLY were observed at 12 and $24 \mathrm{~h}$. DeVries and Chevaux (2014) observed similar drops in ruminal temperature in response to live yeast supplementation and attributed the results partly to more frequent drinking bouts due to the increased meal frequency associated with yeast supplementation.

The total VFA concentrations in the rumen tended to be low, partly because of the low starch concentration of the diet and because mean values reflect the diurnal fluctuation in VFA. Ferraretto et al. (2012) reported that the total ruminal VFA concentration was $105 \mathrm{mM}$ for cows fed a high-starch diet and $89.6 \mathrm{~m} M$ for cows fed a low-starch diet. The unchanged molar proportions of major ruminal VFA, acetate, propionate, and butyrate agree with those reported by Kung et al. (1997) in response to adding live yeast culture to a ruminal continuous culture system using a mixture of $35 \%$ alfalfa, $15 \%$ corn silage, and $50 \%$ concentrate as substrate. The acetate:propionate ratio tended to increase with LLY and HLY and presumably reflects increased ADF and NDF digestibility with supplementation because acetate is one of the primary products of cellulolytic bacteria (Lu et al., 2005).

The beneficial effects of yeast supplementation seem to be less evident when high-forage diets are fed. Mir and Mir (1994) studied the effects of supplementing live yeast culture to steers fed diets differing in grain:forage ratio and reported improved DM digestibility with feeding live yeast culture in steers fed the high-grain $(75 \%)$ diet but not the high-forage diets containing $75 \%$ alfalfa silage or $96 \%$ corn silage. Yeast supplementation improved both DM and NDF degradation in vitro with low-forage diets ( $30 \%$ grass silage), whereas no effects were observed with medium-forage diets (50\% grass silage) or high-forage diets (70\% grass silage; Carro et al., 1992). AlZahal et al. (2014) examined effects of feeding live yeast on ruminal acidosis and animal performance in lactating dairy cows fed high-forage $(77 \%)$ or high-grain $(51 \%)$ diets and reported improved ruminal $\mathrm{pH}$, total VFA concentration, DMI, and 3.5\% FCM production in cows fed the high-grain diet but not the low-grain diet. The greater efficacy of live yeast supplementation to cows consuming higher grain diets is related to diet effects on ruminal $\mathrm{pH}$. Viable yeast can stabilize low pH values (Lynch and Martin, 2002; Chaucheyras-Durand et al., 2005; Fonty and Chaucheyras-Durand, 2006) caused by high-grain diets, resulting in increased fiber digestion and often increased animal performance. High-forage diets do not require yeast for ruminal $\mathrm{pH}$ stabilization because they foster relatively high ruminal $\mathrm{pH}$ and cellulolytic activity.

\section{Associations Between Bacteria Abundance and Performance Measures}

Prevotella is considered the most abundant bacterial genus in both solid and liquid fractions of rumen contents, accounting for 42 to $60 \%$ of the total bacterial population (Stevenson and Weimer, 2007; Jiang et al., 2017). In the present study, Prevotella had negative correlations with DMI and milk fat concentration, and the results are in agreement with a previous study (Jami et al., 2014). However, irrespective of the dose and viability, yeast supplementation had no effects on RA of Prevotella in both solid and liquid ruminal fractions (Jiang et al., 2017).

The RA of Fibrobacter in both liquid and solid fractions correlated positively with milk fat concentration and DMI, which may reflect the presence of F. succinogenes, a major ruminal cellulolytic bacterium (Cato et al., 1978). It is unclear why the RA of Fibrobacter in the solid fraction correlated negatively with milk yield and why Fibrobacter in both fractions correlated positively with milk protein concentration, particularly because the RA of Fibrobacter in both fractions was not changed with yeast supplementation (Jiang et al., 2017).

The positive correlation between RA of Ruminococcus in the solid fraction and ADF digestibility or the positive correlation between Ruminococcus in the liquid fraction with DMI and milk fat concentration may be attributable to the cellulolytic activities of $R$. albus (Ohara et al., 2000) or R. flavefaciens (Stewart et al., 1997). However, for unknown reasons, increasing the live yeast dose increased the RA of Ruminococcus in both fractions but did not increase ADF digestibility, DMI, or milk fat concentration compared with LLY (Jiang et al., 2017).

Ruminal Treponema (species such as Treponema saccharophilum) are known for pectin utilization (Paster 
and Canale-Parola, 1985). Therefore, the explanation for the negative correlation between the RA of Treponema and feed efficiency is unclear. Nevertheless, this result agrees with the fact that LLY, which increased milk production, also reduced the RA of Treponema in the solid fraction. The RA of Ruminobacter was positively correlated with feed efficiency, milk fat, and milk protein concentration, which might be at least partly attributed to the presence of Ruminobacter amylophilus, a starch-degrading bacterial species (Hamlin and Hungate, 1956). Greater abundance of $R$. amylophilus can increase starch utilization, thereby improving milk production and feed efficiency. The reason for the positive correlation between Clostridium and milk protein concentration is not clear. Nevertheless, caution is needed when interpreting the associations found between bacterial abundance and performance parameters in this study because several other factors contribute to the observed performance response.

\section{Bacterial Candidates for Future Research}

To our knowledge, this is the first study showing associations between some unknown rumen bacteria and performance measurements of dairy cows fed live or killed yeast. Lachnospiraceae [Ruminococcus] from the solid fraction and unclassified Paraprevotellaceae in the liquid fraction were positively correlated with milk yield. Unclassified Succinivibrionaceae was positively correlated with ADF digestibility and DMI, whereas unclassified Bacteroidales was positively correlated with DMI, milk fat and protein yield, and feed efficiency. Unclassified Lachnospiraceae, Paraprevotellaceae, and Porphyromonadaceae responded to yeast supplementation and were highly correlated with animal performance parameters. These unknown bacteria should be identified and investigated further to determine their roles.

\section{CONCLUSIONS}

Supplementation with LLY, HLY, or HDY increased in vivo apparent $\mathrm{DM}, \mathrm{NDF}$, and $\mathrm{ADF}$ digestibility, but only LLY supplementation increased milk yield. This study revealed correlations between the performance measures of lactating dairy cattle and RA of their rumen bacteria. Notably, bacterial genera such as Lachnospiraceae, Paraprevotellaceae, and Porphyromonadaceae, which responded to yeast supplementation, were correlated with 1 or more animal performance parameters and hence merit further evaluation in future studies. Future research should also address the differences in the production responses to yeast treatment and explore causative relationships between physiological parameters and rumen microbiota.

\section{ACKNOWLEDGMENTS}

We gratefully acknowledge funding of this study by Dupont Pioneer. We are also grateful to the staff of the University of Florida Dairy Unit for assistance with the study.

\section{REFERENCES}

AlZahal, O., L. Dionissopoulos, A. H. Laarman, N. Walker, and B. W. McBride. 2014. Active dry Saccharomyces cerevisiae can alleviate the effect of subacute ruminal acidosis in lactating dairy cows. J. Dairy Sci. 97:7751-7763.

AOAC International. 2000. Official Methods of Analysis. 17th ed. Assoc. Off. Anal. Chem., Arlington, VA.

Arambel, M. J., and B. A. Kent. 1990. Effect of yeast culture on nutrient digestibility and milk yield responses in early to midlactation dairy cows. J. Dairy Sci. 73:1560-1563.

Bach, A., I. Iglesias, and M. Devant. 2007. Daily rumen pH pattern of loose-housed dairy cattle as affected by feeding pattern and live yeast supplementation. Anim. Feed Sci. Technol. 136:146-153.

Bryant, M. P. 1954. A study of actively cellulolytic rod-shaped bacteria of the bovine rumen. J. Dairy Sci. 37:1176-1183.

Buffington, D. E., A. Collazo-Arocho, G. H. Canton, D. Pitt, W. W. Thatcher, and R. J. Collier. 1981. Black globe-humidity index (BGHI) as comfort equation for dairy cows. Trans. ASAE 24:711-714.

Callaway, E. S., and S. A. Martin. 1997. Effects of a Saccharomyces cerevisiae culture on ruminal bacteria that utilize lactate and digest cellulose. J. Dairy Sci. 80:2035-2044.

Carro, M. D., P. Lebzien, and K. Rohr. 1992. Influence of yeast culture on the in vitro fermentation (Rusitec) of diets containing variable portions of concentrates. Anim. Feed Sci. Technol. 37:209-220.

Cato, E. P., W. E. C. Moore, and M. P. Bryant. 1978. Designation of neotype strains for Bacteroides amylophilus Hamlin and Hungate 1956 and Bacteroides succinogenes Hungate 1950. Int. J. Syst. Evol. Microbiol. 28:491-495.

Chaucheyras-Durand, F., and G. Fonty. 2002. Influence of a probiotic yeast (Saccharomyces cerevisiae CNCM I-1077) on microbial colonization and fermentation in the rumen of newborn lambs. Microb. Ecol. Health Dis. 14:30-36.

Chaucheyras, F., G. Fonty, and G. Bertin., G, J. M. Salmon, and P. Gouet. 1996. Effects of a strain of Saccharomyces cerevisiae (Levucell SC), a microbial additive for ruminants, on lactate metabolism in vitro. Can. J. Microbiol. 42:927-933.

Chaucheyras-Durand, F., S. Masseglia, and G. Fonty. 2005. Effect of the microbial feed additive Saccharomyces cerevisiae CNCM I-1077 on protein and peptide degrading activities of rumen bacteria grown in vitro. Curr. Microbiol. 50:96-101.

Dann, H. M., J. K. Drackley, G. C. McCoy, M. F. Hutjens, and J. E. Garrett. 2000. Effects of yeast culture (Saccharomyces cerevisiae) on prepartum intake and postpartum intake and milk production of Jersey cows. J. Dairy Sci. 83:123-127.

de Ondarza, M. B., C. J. Sniffen, L. Dussert, E. Chevaux, J. Sullivan, and N. Walker. 2010. Case study: Multiple-study analysis of the effect of live yeast on milk yield, milk component content and yield and feed efficiency. Prof. Anim. Sci. 26:661-666.

Desnoyers, M., S. Giger-Reverdin, G. Bertin, C. Duvaux-Ponter, and D. Sauvant. 2009. Meta-analysis of the influence of Saccharomyces cerevisiae supplementation on ruminal parameters and milk production of ruminants. J. Dairy Sci. 92:1620-1632.

DeVries, T. J., and E. Chevaux. 2014. Modification of the feeding behavior of dairy cows through live yeast supplementation. J. Dairy Sci. 97:6499-6510. 
Duniere, L., L. Jin, B. Smiley, M. Qi, W. Rutherford, Y. Wang, and T. McAllister. 2015. Impact of adding Saccharomyces strains on fermentation, aerobic stability, nutritive value, and select lactobacilli populations in corn silage. J. Anim. Sci. 93:2322-2335.

Elghandour, M. M., J. C. V. Chagoyán, A. Z. Salem, A. E. Kholif, J. S. M. Castañeda, L. M. Camacho, and M. A. Cerrillo-Soto. 2014. Effects of Saccharomyces cerevisiae at direct addition or preincubation on in vitro gas production kinetics and degradability of four fibrous feeds. Ital. J. Anim. Sci. 13:295-301.

Ferraretto, L. F., R. D. Shaver, and S. J. Bertics. 2012. Effect of dietary supplementation with live-cell yeast at two dosages on lactation performance, ruminal fermentation, and total-tract nutrient digestibility in dairy cows. J. Dairy Sci. 95:4017-4028.

Fonty, G., and F. Chaucheyras-Durand. 2006. Effects and modes of action of live yeasts in the rumen. Biologia (Bratisl.) 61:741-750.

García, C. C. G., M. G. D. Mendoza, M. S. González, P. M. Cobos, C. M. E. Ortega, and L. R. Ramirez. 2000. Effect of a yeast culture (Saccharomyces cerevisiae) and monensin on ruminal fermentation and digestion in sheep. Anim. Feed Sci. Technol. 83:165-170.

Ghoneem, W. M., and A. E. M. Mahmoud. 2014. Effect of in-activated and dried yeast on productive performance of Barki lambs. Asian J. Anim. Vet. Adv. 9:664-673.

Gochman, N., and J. M. Schmitz. 1972. Application of a new peroxide indicator reaction to the specific, automated determination of glucose with glucose oxidase. Clin. Chem. 18:943-950.

Guedes, C. M., D. Goncalves, M. A. M. Rodrigues, and A. Dias-daSilva. 2008. Effect of yeast Saccharomyces cerevisiae on ruminal fermentation and fiber degradation of maize silage in cows. Anim. Feed Sci. Technol. 145:27-40.

Hamlin, L. J., and R. E. Hungate. 1956. Culture and physiology of a starch-digesting bacterium (Bacteroides amylophilus n. sp.) from the bovine rumen. J. Bacteriol. 72:548-554.

Hasunuma, T., Y. Uyeno, K. Akiyama, S. Hashimura, H. Yamamoto, H. Yokokawa, T. Yamaguchi, M. Itoh, H. Mizuguchi, S. Sato, and M. Hirako. 2016. Consecutive reticular $\mathrm{pH}$ monitoring in dairy cows fed diets supplemented with active dry yeast during the transition and mid-lactation periods. Anim. Feed Sci. Technol. $221: 215-225$

Jami, E., B. A. White, and I. Mizrahi. 2014. Potential role of the bovine rumen microbiome in modulating milk composition and feed efficiency. PLoS One 9:e85423.

Jiang, Y., I. M. Ogunade, T. J. Hackmann, C. Staples, and A. T. Adesogan. 2017. Effects of the dose and viability of Saccharomyces cerevisiae. 1. Diversity of ruminal microbes as analyzed by Illumina MiSeq sequencing and qPCR. J. Dairy Sci. 100:325-342.

Jouany, J. P. 2006. Optimizing rumen functions in the close-up transition period and early lactation to drive dry matter intake and energy balance in cows. Anim. Reprod. Sci. 96:250-264.

Kincaid, C. 2005. Guidelines for selecting the covariance structure in mixed model analysis. Pages 1-8 in Proc. 30th Annual SAS Users Group International Conference (No. 198-30). SAS Institute Inc., Cary, NC.

Kung, L., E. M. Kreck, R. S. Tung, A. O. Hession, A. C. Sheperd, M. A. Cohen, H. E. Swain, and J. A. Z. Leedle. 1997. Effects of a live yeast culture and enzymes on in vitro ruminal fermentation and milk production of dairy cows. J. Dairy Sci. 80:2045-2051.

Lu, C. D., J. R. Kawas, and O. G. Mahgoub. 2005. Fibre digestion and utilization in goats. Small Rumin. Res. 60:45-52.

Lynch, H. A., and S. A. Martin. 2002. Effects of Saccharomyces cerevisiae culture and Saccharomyces cerevisiae live cells on in vitro mixed ruminal microorganism fermentation. J. Dairy Sci. 85:26032608.

Marden, J. P., C. Julien, V. Monteils, E. Auclair, R. Moncoulon, and C. Bayourthe. 2008. How does live yeast differ from sodium bicarbonate to stabilize ruminal $\mathrm{pH}$ in high-yielding dairy cows? J. Dairy Sci. 91:3528-3535.

Marsh, W. H., B. Fingerhut, and H. Miller. 1965. Automated and manual direct methods for the determination of blood urea. Clin. Chem. 11:624-627.
Miller-Webster, T., W. H. Hoover, M. Holt, and J. E. Nocek. 2002. Influence of yeast culture on ruminal microbial metabolism in continuous culture. J. Dairy Sci. 85:2009-2014.

Mir, Z., and P. S. Mir. 1994. Effect of the addition of live yeast ( $\mathrm{Sac}$ charomyces cerevisiae) on growth and carcass quality of steers fed high-forage or high-grain diets and on feed digestibility and in situ degradability. J. Anim. Sci. 72:537-545.

Miron, J., D. Ben-Ghedalia, and M. Morrison. 2001. Invited review: Adhesion mechanisms of rumen cellulolytic bacteria. J. Dairy Sci. 84:1294-1309.

Moallem, U., H. Lehrer, L. Livshitz, M. Zachut, and S. Yakoby. 2009. The effects of live yeast supplementation to dairy cows during the hot season on production, feed efficiency, and digestibility. J. Dairy Sci. 92:343-351.

Mosoni, P., F. Chaucheyras-Durand, C. Bera-Maillet, and E. Forano. 2007. Quantification by real-time PCR of cellulolytic bacteria in the rumen of sheep after supplementation of a forage diet with readily fermentable carbohydrates: Effect of a yeast additive. J. Appl. Microbiol. 103:2676-2685.

Muck, R. E., and J. T. Dickerson. 1988. Storage temperature effects on proteolysis in alfalfa silage. Trans. ASABE 31:1005-1009.

Mwenya, B., B. Santoso, C. Sar, B. Pen, R. Morikawa, K. Takaura, K. Umetsu, K. Kimura, and J. Takahashi. 2005. Effects of yeast culture and galacto-oligosaccharides on ruminal fermentation in Holstein cows. J. Dairy Sci. 88:1404-1412.

Newbold, C. J., R. J. Wallace, and F. M. McIntosh. 1996. Mode of action of the yeast Saccharomyces cerevisiae as a feed additive for ruminants. Br. J. Nutr. 76:249-261.

Noel, R. J., and L. G. Hambleton. 1976. Collaborative study of a semiautomated method for determination of crude protein in animal feeds. J. Assoc. Off. Anal. Chem. 59:134-140.

NRC. 2001. Nutrient Requirements of Dairy Cattle. 7th rev. ed. Natl. Acad. Sci., Washington, DC.

Oeztuerk, H. 2009. Effects of live and autoclaved yeast cultures on ruminal fermentation in vitro. J. Anim. Feed Sci. 18:142-150.

Ohara, H., S. Karita, T. Kimura, K. Sakka, and K. Ohmiya. 2000. Characterization of the cellulolytic complex (cellulosome) from Ruminococcus albus. Biosci. Biotechnol. Biochem. 64:254-260.

Opsi, F., R. Fortina, S. Tassone, R. Bodas, and S. López. 2012. Effects of inactivated and live cells of Saccharomyces cerevisiae on in vitro ruminal fermentation of diets with different forage:concentrate ratio. J. Agric. Sci. 150:271-283.

Ouellet, D. R., and J. Chiquette. 2016. Effect of dietary metabolizable protein level and live yeasts on ruminal fermentation and nitrogen utilization in lactating dairy cows on a high red clover silage diet. Anim. Feed Sci. Technol. 220:73-82.

Paster, B. J., and E. Canale-Parola. 1985. Treponema saccharophilum sp. nov., a large pectinolytic spirochete from the bovine rumen. Appl. Environ. Microbiol. 50:212-219.

Pinloche, E., N. McEwan, J.-P. Marden, C. Bayourthe, E. Auclair, and C. J. Newbold. 2013. The effects of a probiotic yeast on the bacterial diversity and population structure in the rumen of cattle. PLoS One 8:e67824.

Poppy, G. D., A. R. Rabiee, I. J. Lean, W. K. Sanchez, K. L. Dorton, and P. S. Morley. 2012. A meta-analysis of the effects of feeding yeast culture produced by anaerobic fermentation of Saccharomyces cerevisiae on milk production of lactating dairy cows. J. Dairy Sci. 95:6027-6041.

Querol, A., E. Barrio, and D. Ramo'n. 1992. A comparative study of different methods of yeast strain characterization. Syst. Appl. Microbiol. 15:439-446.

Roa, M. L., J. R. Bárcena-Gama, S. González, G. Mendoza, M. E. Ortega, and C. Garciá. 1997. Effect of fiber source and a yeast culture (Saccharomyces cerevisiae ${ }^{1026}$ ) on digestion and the environment in the rumen of cattle. Anim. Feed Sci. Technol. 64:327-336.

Robinson, P. H. 2002. Yeast products for growing and lactating dairy cattle: Impacts on rumen fermentation and performance. Pages 1-12 in Proc. XII Int. Mtg. Milk Meat Prod. Hot Clim., Mexicali, Mexico. 
Robinson, P. H., and L. J. Erasmus. 2009. Effects of analyzable diet components on responses of lactating dairy cows to Saccharomyces cerevisiae based yeast products: A systematic review of the literature. Anim. Feed Sci. Technol. 149:185-198.

Rossi, F., A. D. Luccia, D. Vincenti, and P. S. Cocconcelli. 2004. Effects of peptidic fractions from Saccharomyces cerevisiae culture on growth and metabolism of the ruminal bacteria Megasphaera elsdenii. Anim. Res. 53:177-186.

Schneider, B. H., and W. P. Flatt. 1975. The indicator method. Page 168 in The Evaluation of Feeds Through Digestibility Experiments. University of Georgia Press, Athens.

Stevenson, D. M., and P. J. Weimer. 2007. Dominance of Prevotella and low abundance of classical ruminal bacterial species in the bovine rumen revealed by relative quantification real-time PCR. Appl. Microbiol. Biotechnol. 75:165-174.

Stewart, C. S., H. J. Flint, and M. P. Bryant. 1997. The rumen bacteria. Pages 10-72 in The Rumen Microbial Ecosystem. P. N. Hobson and C. S. Stewart, ed. Springer, Dordrecht, the Netherlands.

Van Soest, P. J., J. B. Robertson, and B. A. Lewis. 1991. Symposium: Carbohydrate methodology, metabolism and nutritional implications in dairy cattle. Methods for dietary fiber, neutral detergent fiber, and nonstarch polysaccharides in relation to animal nutrition. J. Dairy Sci. 74:3583-3597.

Vyas, D., A. Uwizeye, R. Mohammed, W. Z. Yang, N. D. Walker, and K. A. Beauchemin. 2014. The effects of active dried yeast and killed dry yeast on subacute rumen acidosis, ruminal fermentation and nutrient digestibility in beef heifers. J. Anim. Sci. 92:724-732.

Ward, R. 2011. Analyzing silage crops for quality: What is most important? Pages 46-65 in Proc. Western Alfalfa and Forage Conference, Univ. California, Davis. Cooperative Extension, Plant Sciences Department, University of California, Davis.

Weimer, P. J. 1996. Why don't ruminal bacteria digest cellulose faster? J. Dairy Sci. 79:1496-1502.

Williams, C. H., D. J. David, and O. Iismaa. 1962. The determination of chromic oxide in feces samples by atomic absorption spectrophotometry. J. Agric. Sci. 59:381-385.

Wohlt, J. E., T. T. Corcione, and P. K. Zajac. 1998. Effects of yeast on feed intake and performance of cows fed diets based on corn silage during early lactation. J. Dairy Sci. 81:1345-1352.

Wohlt, J. E., A. D. Finkelstein, and C. H. Chung. 1991. Yeast culture to improve intake, nutrient digestibility, and performance by dairy cattle during early lactation. J. Dairy Sci. 74:1395-1400. 